\title{
EFL learners' perspective on English Honorifics (EHs) in Indonesia
}

\author{
${ }^{1}$ Rina Herlina*, ${ }^{1}$ Wawan Tarwana \\ Faculty of Teacher Training and Education, Universitas Galuh, Indonesia \\ *Corresponding Author: \\ Email: rherlina85@yahoo.co.id
}

$\begin{array}{llll}\text { Received: } & \text { Revised: } & \text { Accepted: } & \text { Published: } \\ \text { 11 June 2020 } & \text { 30 July 2020 } & \text { 31 July 2020 } & \text { 31 July 2020 }\end{array}$

\begin{abstract}
Indonesian EFL learners (IELs) have been familiar with the practice of English Honorifics/EHs (Mr, Mrs, Miss, Sir and Ma'am) for decades. Mr, Mrs, Miss are followed by family name as the clan identity and Sir and Ma'am are for respectful address for adult man and woman. However, in Indonesia, it's been the phenomenon because there seem to be a collision between how EFL learners practice EHs with what EHs are supposed to be used in English culture. The purpose of this study is to clarify and verify how Indonesian EFL learners perceive on EHs that have been interpreted and practiced for decades in Indonesia. This study applies double approaches. First, cross cultural study which employs content analysis by means of analyzing how EHs are interpreted and practiced under the setting of Indonesian culture. The sources to be analyzed are obtained from English handouts, chats and texts in social media among EFL students, as well as script deriving from teacher-EFL students' classroom interaction. Second, case study which employs triangulation technique to examine some aforementioned sources. The result reveals that Indonesian EFL learners perceive that the practice of EHs (Mr, Mrs, Miss, Sir, Ma'am) have no difference with the ones applied in Indonesian culture. It means that there is no more difference in function between Mrs and Miss, Ma'am, Mr and Sir. Those have been considered the same in practice with Indonesian Honorifics (IHs) like ibu (Ma'am), bapak $(\mathrm{Mr})$, nyonya (Mrs), dan nona (Miss) even though they have different function. These have been conducted beyond EFL learners' culture awareness of how native speaker of English uses EHs because there is an assumption that learning English doesn't include learning its culture. For most Indonesian EFL learners, learning English as a foreign language is a matter of learning basic skills and linguistic features. So, if there are any further cultural encounters during learning English, they will be switched automatically to Indonesian culture. This study recommends English teachers to keep teaching English culture during teaching English in order to avoid learners' misunderstanding in communication with English speaking people.
\end{abstract}

Keywords: EFL learners; English Honorifics (EHs); Indonesian Honorifics (IHs); the practice; Culture

\section{INTRODUCTION}

Interpreting English words containing cultures is not the same as interpreting ordinary English words because culture means a way of life which containing values, norms, beliefs, thoughts, etc. However, it seems an invisible aspect, (Hermessi, 2016; Rajab, 2015). Therefore, most Indonesian EFL learners never take it into consideration, such as 
Herlina, R., \& Tarwana, W. (2020). EFL learners' perspective on English Honorifics (EHs) in Indonesia. Journal of Advanced Multidisciplinary Research, 1 (1), 32-45. DOI: http://dx.doi.org/10.30659/JAMR.1.1.32-45

in learning English as foreign language. For most Indonesian EFL learners, learning English is a matter of learning basic skills and linguistic features. Cultural awareness can be additional matter which is not supposed to focus on which means EFL learners never deals with the essence of English words containing cultural aspects (Constantine, Vida, Popescu, 2015).

English words containing cultural aspects can be found elsewhere not only in school handouts but also in spoken English in different setting, either formal or informal. One of which is EHs such as, Mr, Mrs, Miss, ma'am and sir that have been used in English speaking countries addressing to a person with respect. $\mathrm{Mr}$ Smith, Mrs Smith, and Miss Smith mean that Smith belongs to Smith clan or family identity. $M s$ refers to a woman who is married or not. This is purposed by feminist who put priority on gender equivalence (Brown and Levinson, 1978; Wardhaugh, 1986).

The phenomenon of EHs in Indonesia is displayed also in daily life when some of people address a foreigner, usually with white skin and blond hair, 'Mister' for a man (without being followed by family name) and ' $m r s$ ' for a woman (without being followed by husband's last name). The switching in addressing EHs to the foreigner occurs in almost all level of life aspects such as in education, economy, and other social interaction.

Native speaker of English has EHs e.g., sir, miss, mrs, mr, ma'am. They are basically called Honorific Title used for younger and older people. Some of them are used to show respect to them. The following examples and descriptions clarify the use of EHs.

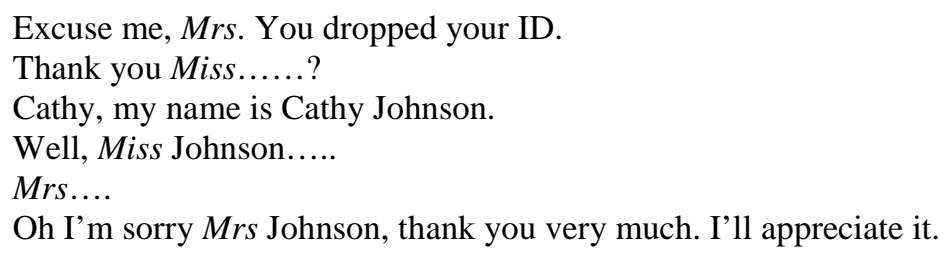

Mrs is an EH to give honor for a married or widow woman. Sometimes that title includes her husband's first and last name rather than her own, especially for written correspondence or when the wife's name is unknown. This practice is becoming far less common than it was Both Miss and Ms apply to women who are unmarried or whose marital status is unknown. Which you choose depends on the preference of the woman. The use of 'ma'am/madam' without a name when speaking to older female service workers. This shows respect for their age.

I beg your pardon, ma'am.

Could you help me, ma'am?

I would appreciate your help, ma'am.

Indonesian mispronounce of ma'am is mom which is supposed to be the pronunciation for mom or mum that means mother. This misunderstanding has been lasting for decades It can be found during teacher-students' class interaction or in 
various learning materials. Thus, this study focuses on cultural study that EPTs containing cultural aspects into the context of Indonesian culture.

The research question of this study focuses on what is EFL's learners' perspective on $\mathrm{Mr}$, Miss, Mrs, Ma'am/madam and Sir in Indonesian language. Related research conducted by Aghajanian and Cong (2012) highlights How Culture effects on English Language Learners' (ELL's) Outcomes, with Chinese and Middle Eastern Immigrant Students. The study shows the challenges that the students encounter. It recommends on how schools and teachers can be better to respond on the needs of EFL students from different cultures. It also concludes different cultures. However, the present study only focuses on one specific culture, Indonesian culture, compared to English culture. In fact, English loan words such as $M r, M r s$, and Miss are commonly used when there is no title on hand. Understanding how to use EHs is a part of understanding English culture where British and American become the target culture. Willy-nilly, if anyone learns English for all purposes. It means that s/he has to learn its culture because. The great significance role of English culture in learning English can successfully contribute the benefits to ultimate learning achievement

In the English language in Wikipedia, an English Honorific is a form of address indicating respect. These can be titles prefixing a person's name, e.g.: Mr, Mrs, Miss, $M s, M x$, Sir, Dr, Lady or Lord, or titles or positions that can appear as a form of address without the person's name, as in Mr President, General, Captain, Father, Doctor or Earl. Here are the formal titles English speakers use according to wikipedia:

Table 1. English Honorifics and its function

\begin{tabular}{ll}
\hline English Honorifics & Function \\
\hline Sir & Adult male of any age or for men, formally if they have a British knighthood \\
& or if they are a baronet (used with first name or full name, never surname \\
& alone) or generally (used on its own) as a term of general respect or flattery, \\
& when it is equivalent in meaning to "Madam" for women (see below). Also \\
& traditionally used to address male teachers in British schools \\
\hline Ma'am or Madam & Adult female - North American. For women, a term of general respect or \\
(North American) & flattery. Originally used only to a woman of rank or authority. May also refer \\
& to a female pimp. Equivalent to "Sir". All of "Sir", Madam", and "Ma'am" are \\
& commonly used by workers performing a service for the beneficiary of the \\
& service, e.g. "May I take your coat, Ma'am?" "Madam" is used with the name \\
& of an office to address a woman who is the office-holder, e.g. "Madam \\
& President". \\
\hline Mr & $\begin{array}{l}\text { last name (any man) or for men, regardless of marital status, who do not have } \\
\text { another professional or academic title. The variant Mister, with the same } \\
\text { pronunciation, is sometimes used to give jocular or offensive emphasis, or to } \\
\text { address a man whose name is unknown. "Mr" is used with the name of some } \\
\text { offices to address a man who is the office-holder, e.g. "Mr President"; "Mr } \\
\text { Speaker", see "Madam" below for the equivalent usage for women. }\end{array}$ \\
\hline Last name (married woman who uses her husband's last name). for married \\
women who do not have another professional or academic title. The variant \\
Missus (/'misəz/) is used in the UK to address a woman whose name is
\end{tabular}


Herlina, R., \& Tarwana, W. (2020). EFL learners' perspective on English Honorifics (EHs) in Indonesia. Journal of Advanced Multidisciplinary Research, 1 (1), 32-45. DOI: http://dx.doi.org/10.30659/JAMR.1.1.32-45

married women who continue to use their maiden name (although "Ms" is often preferred for the last two). In the UK, it has traditionally been used in schools to address female teachers, regardless of marital status. It is also used, without a name, to address girls or young women and (in the UK) to address female shop assistants and wait staff

Hijirida and Sohn (1983) have done a good foundational work on both Korean and American English. The following is the quoted description of possible address forms, adapted from them: 'Miss, Mrs., and Ms. are not interchangeable terms. Choosing the wrong title can cause offense, so it's important to know the difference between the three titles. The guide below will describe how the titles Miss, Mrs., and Ms. have been used traditionally_but remember, if someone tells you they prefer a particular title, that's the one you should use to address them. Miss, when attached to a name, is a title of respect for an unmarried woman. You can use it by itself as a term of address or combine it with a surname, a descriptor of a prominent characteristic, or something she represents.

KOVÁCS (2017) stated that culture is the compilation of programming the thoughts to differentiate one community from others. It can be also said that culture is the entire ways of living developed by a group of human beings transferred from one generation over next generation (Biggs and Moore, 1993, p. 24: Genc and Bada, 2005). In practice, culture leads to people classification in accordance with in various life aspects as Kennedy (2002, p. 1) defines culture "as not merely a matter of unconcealed behavior, but also inclusive with social norms, thoughts, attitudes and value that manage how people do, speak and describe themselves" (Keaton, Giles, 2015). Due to the fact that culture is greatly distinct, different frameworks could differentiate various types of culture. However, Sapir (1949) cited in Abushihab (2016) highlighted that 'language, race, and culture are not highly connected', emphasizing the remark 'language and our entire thoughts are inseparably correlated. However, this statement does not uphold an adequate support to the theory that culture teaching ought to be in line with language education. Some main umbrellas of teaching culture implicitly and explicitly in teaching languages provided by Kitao, Stainer, Chastain, Gardner and Lambert (1959, 1965, 1971, 1972, 2000) as follows:

- Learning culture during learning the target language can comprehend the language meaningfully and it is such a potential enrichment for EFL learners (Pourkalhor, O. \& Esfandiari, N., 2017).

- From the perspective of foreign learners, apprehending the native speaker of target language as real person is definitely one of the main problems in language teaching. Even though, all authentic experiences or genuine examples from native speaker's real life have been displayed in English handouts at school, however foreign learners might still consider it fictitious due to the absence of background knowledge of those speaker's real life. Thus, engaging to cultural aspect of language could scaffold foreign learners relate the abstract sounds and forms of a language to real people and places (Abbaspour, Nia, Zare, 2012; Gay, 2002: 106). 
- Some motivations come up during studying English that is also in line with what have been said by some experts (Genc and Bada, 2005; Turkan and çelik, 2007; Neff and Rucynski, 2013) cited in Abushihab (2016). Because most people are keen on art activities like singing, dancing, role playing, drama, they have curiosity to get to know deeply how the languages are spoken. In short, learning a language could come from knowing and adoring its art performance. Today, K-Pop culture is number one-most liked worldwide. It leads people, in particular, learn Korean language and its culture. The good thing that could be taken from learning culture in teaching any language is people become tolerable towards the diversity in terms of nationalities, ideologies, customs, and religions (Moeller \& Nugent 2014: 14; Kramsch, 2009). Some misunderstanding of a language because of its culture misunderstanding can be avoided. Obviously, any culture confrontation will be avoided as well, Gay (2002: 106). This highpoint is also stressed by Kramsch (2001). He emphasizes that such a society from groups like ethnic, nation, neighborhood, professional or ethnic affiliation have to possess common ways of how to conduct interaction with other members of the same group. These interactions can be seen in social groups such as, family, social gatherings, school, workplace, religion community, government, and others during their lives. All are in line with the language they use. They have selection of how to say and how they say it.

Nunan \& Richards (2015) makes reinforcement that studying culture puts some benefits for learners to get interested in the target language' native speaker. Another benefit is learners can also learn other aspects like learning about geography, history, etc. of the target culture.

To support that argument, Wardhaugh \& Fuller (2015), underline two methods how culture influences language teaching; 1) Linguistically, culture influences the language features such as semantic and pragmatic (Liang,2016; Geng, 2018). 2) Pedagogically, culture affects the selection of the language materials because cultural content of the language materials and the cultural basis of the teaching methodology are to be taken into consideration while deciding upon the language materials. For example, while some textbooks provide examples from the target culture, some others use source culture materials.

The theory that culture has always been embedded, particularly in its contribution to language education, is still in blurred (Vahdany, 2005, p. 93; Sysoyev \& Donelson, 2002; Bada, 2000: 101). It makes sense quite enough because language teaching curriculum never put the priority on the culture that makes foreign learners get more distant from culture awareness.

There is a related study with the present study discussing about Terms of Address in Korean and American Cultures provided by Hwang (1991). This paper studies different orientations and different orderings of constituents in address terms used in Korean and American cultures. However, this present study focuses on addressing or the practice of EHs in Indonesia considering that culture awareness in Indonesia is still not increasing 
Herlina, R., \& Tarwana, W. (2020). EFL learners' perspective on English Honorifics (EHs) in Indonesia. Journal of Advanced Multidisciplinary Research, 1 (1), 32-45. DOI: http://dx.doi.org/10.30659/JAMR.1.1.32-45

\section{METHOD}

This study has qualitative approach which case study is applied because it analyzes and describes scaffolding as a case in teaching non reciprocal listening to students. Fraenkel \& Wallen (2007) stated that what case study researchers have in common is that they call the object of their research cases, and they focus their research on the study of such cases.

This study may also employ Cross-cultural research which needs deep and further detailed-elaborated analysis of a two culture comparison, namely Indonesian and English cultures. Cross-cultural research is a scientific method of comparative research which focuses on systematic comparisons that compares culture to culture and explicitly aims to answer questions about the incidence, distributions, and causes of cultural variation and complex problems across a wide domain, usually worldwide (Olatundun, 2009). Exploring various digital and spoken discourses greatly a part of content analysis as the data analysis technique. It requires also Triangulation to validate the data. It is a way to get to the finding in the first place by seeing or hearing multiple instances of it from different sources by using different methods and by squaring the finding with others it needs to be squared with analytic induction, once again (Miles \& Huberman \& Saldana, 2014). Those techniques examined some instruments obtained from English school handouts, classroom observation record and chats from web sources. Finally, interpreting all data will be in the form of narration and tables to display the research objectivity and conformity.

\section{RESULTS AND DISCUSSION}

Mr, Mrs, Miss, sir, and ma'am can be frequently found in English handouts in all level of education in Indonesia. Started from elementary school until higher education level. Not only in school handouts but also in classroom interaction among EFL students and their English teacher, such as in greeting and other learning activities like role play and drama. EFL students always address their female teacher with the personal title 'Mrs or Miss' depending on whether the female teacher is married or single and they address the male teacher with ' $\mathrm{Mr}$ ' no matter he is married or not. Sometimes they address female English teacher with ma'am. The following data were compiled from different school handouts and recorded from classroom interaction in English class.

Table 2. English handout "when English rings a bell" grade 7

\begin{tabular}{ll}
\hline Page 28 & Beni, will you close the window, please? Certainly, Sir. \\
\hline Page 29 & Mrs Wulandari: "the little boy is very spoilt" \\
\hline Page 93 & Mr. Ahmad feeds the animals every day \\
\hline Page 183 & In the back seats, my mum was holding Mrs. Wayan. \\
\hline Page 202 & Mom I'm sorry I did not have time to wash the dishes \\
\hline Page 58 & May I wash my hands ma'am? \\
\hline
\end{tabular}


EFL students always address their English teacher $M r$, Mrs, Miss rather than ibu or bapak (Indonesian personal titles for Mrs and $M r$ ). Pak 'Sir" in page 28. They affect their English with their own culture. They do not do this on purpose because they think culture doesn't matter so much in learning English. They are not aware of the real meaning of $M r$, Mrs, Miss. Native speakers of English use them all after the family names. John Smith will be called Mr. Smith. Mrs Smith means John Smith's wife. Miss Smith means John Smith's daughter. In addition, John Smith's son will be called Mr. Smith. Those are only applied in formal setting and polite attribute. In contrast, in when English rings a bell grade 7, Mrs, Miss, Mrs don't display the clan because in most Indonesian culture, personal titles like bapak, ibu, nyonya, tuan, nona are not followed by family name. Only $i b u$ and nyonya can be followed by their husbands' last names. However, they're just followed by first names or even full names, such as Mrs Wulandari, Mrs, wayan, and $M r$ Ahmad and in other higher grade's handouts full names are applied, such as Mrs Rina Andriani, $M r$, Hiroko Nomoto, Miss Wina Kartasasmita, etc. in the case of Mrs Wina Kartasasmita, coincidently last name belongs to family identity. However, Mrs Kartasasmita is not applied. Sir, doesn't have any change at all in meaning when it is applied in the context of Indonesian culture including addressing male teachers at school whether he is married or not. In page 183 'mum', page 202 'mom', and page 58 'ma'am' have been stuck to the same pronunciation as 'mom'. EFL students seem to conclude so. Whilst 'ma'am' is pronounced 'moem' just like in 'cat' and 'hand'.

\section{Classroom interaction in English Education Program semester 1}

The following script is taken from recorded class observation in speaking class between a teacher of English and students;

Teacher: good morning class.

Students: good morning Mrs Listi (Listiana Nurhakim is the full name and she was not married at that time)

Teacher: did you do your homework?

Students: yes, Ma'am (the pronunciation is the same with mom for mother)

Students a: Miss, could you tell me whether our homework must be submitted online?

The inconsistency of EFL students seems obvious. They use Mrs and Miss to the teacher. When student a addressed the teacher 'miss', he or they could be all students are not aware of the existence of that EPTs. In this case, Listiana Nurhakim is married, so the proper personal title for her is ' $M r s$ '. Some reasons could explain why it happens. First, the teacher knows the function of each personal title but he never transfer that knowledge to the students. Second, EFL students know already the function of those personal titles but Indonesian culture affect them so much so they ignore the existence of personal titles. They assume that it's fine to adapt those personal titles to the context of Indonesian culture. They feel comfortable to apply those EPTs to Indonesian culture.

Comments of subscribers in language learningTutorial You Tube Comment 1: miss Rina Herlina, could you speak English with British accent? Comment 2: thank you mrs Herlina to teach our 
Herlina, R., \& Tarwana, W. (2020). EFL learners' perspective on English Honorifics (EHs) in Indonesia. Journal of Advanced Multidisciplinary Research, 1 (1), 32-45. DOI: http://dx.doi.org/10.30659/JAMR.1.1.32-45

Comment 3: please mum teach me more

Comment 1 until comment 3 express that they are not really aware of the real use of EPTs. They think the way they address people using EPTs is the same as it is in Indonesian culture like addressing people with bapak, ibu, nyonya, etc. However, it is confusing as well for addressing Indonesian person like Rina Herlina who doesn't put her clan name. Therefore, both mrs and miss may be proper in this case. The following script taken from YouTube is the example of how a young woman was a bit offended when an Indonesian seller in Kuta Bali addressed her with wrong EPTs;

Seller: $\quad$ mrs...mrs....please buy this bracelet....nice bracelet

Young woman: excuse me, do I look very old?

Seller: You very young and beauty.... want buy $m r s$ ?

Young woman: you've got to address me miss...ok...sorry I'm not interested in your bracelet

That misunderstanding of EHs practice, between a seller and young woman, could be a bad impact for economy aspect because the different status between miss and mrs. That could make native speakers furious.

The following quotation of EHs was displayed in opening speech for an International school inauguration;

"Excellency Mr. Jeremy Thompson, the president, Mr. Steven William, the vice president and all beloved new students of X international school good morning and ....."

In that opening speech, it should be Mr. Thompson because he is from USA which means native speaker of English where he is always called Mr. Thompson in his country. And it should be Mr. William because he comes from Australia which means also he is native speaker and in his country he is always called Mr. William. However, the master of ceremony is an Indonesia person, so the culture negotiation occurred.

That misunderstanding of EHs practice, between a seller and young woman, could be a bad impact for economy aspect because the different status between miss and mrs. That could make native speakers furious and they refuse making next transaction. This is not the only case. Other same cases because of misunderstanding of EHs practice regularly occur usually in tourism areas where interaction among native speakers of English and Indonesian sellers, vendors, and traders takes place.

Thus, the finding of the study show that Indonesian EFL learners perceive and use EPTs at the same way with Indonesian Honorifics (IHs) like $i b u$ (respectful address for adult female without considering she is married or not), bapak (respectful address for adult male without considering he is married or not), nyonya (respectful address for adult female by using her husband full name; her husband's name, for instance, is Joko Widodo, and his wife is called nyonya Joko Widodo). They use mrs and miss interchangeably both to married and unmarried woman. In the case of ma'am/madam, the pronunciation is just like to mother $/ \mathrm{mom} /$ as it is elaborated in table 3 . They are not aware if $/ \mathrm{mom} /$ or $/ \mathrm{m} / \mathrm{m} /$ must be for real mother and $/ \mathrm{ma}^{\prime} \mathrm{am} /$ is a respectful address for a woman, married or not married. There is no problem with $m r$ and sir because both EHs can be for married and unmarried man. If Indonesian people use EHs for other 
Indonesian, it is not a big deal. However, if this misuse of EHs is addressed to native speakers of English, they'll be offensive.

The following table contains the comparison between the use of EHs in the version of native speaker of English and Indonesian version:

Table 3. The comparison between EHs original version and Indonesian version

\begin{tabular}{|c|c|c|}
\hline Name or English Honorifics & Native speaker version (NSV) & Indonesian version \\
\hline $\begin{array}{l}\text { Budi Wijaya (Wijaya is not } \\
\text { family name because most } \\
\text { Indonesian people do not } \\
\text { practice family name) }\end{array}$ & $M r$. Wijaya & $M r$. Budi Wijaya \\
\hline $\begin{array}{l}\text { Allison Sue Baker (Baker is } \\
\text { the last name of Allison's } \\
\text { husband, John Baker) }\end{array}$ & Mrs. Baker & Mrs. Allison Sue Baker \\
\hline $\begin{array}{l}\text { Joan Hannah Baker (Baker is } \\
\text { the last name of Joan's father, } \\
\text { John Baker) }\end{array}$ & Miss. Baker & Miss. Joan Hannah Baker \\
\hline ( & 'Thank you, sir' & $\begin{array}{l}\text { 'Thank you Mister' (most } \\
\text { Indonesian people is more } \\
\text { familiar with mister than sir) }\end{array}$ \\
\hline Ma'am/madam & $\begin{array}{l}\text { Yes, ma'am/madam } \\
\text { The real pronunciation is /mcem/ and } \\
\text { /mcedom/ }\end{array}$ & $\begin{array}{l}\text { Most Indonesian people } \\
\text { pronounce it } / \mathrm{mom} / \text { just like for } \\
\text { mommy (mother) or } / \mathrm{m} \Lambda \mathrm{m} / \text { just } \\
\text { like in pronouncing cup, hug or } \\
\text { nut. Madam is never used in } \\
\text { Indonesia }\end{array}$ \\
\hline
\end{tabular}

Table 3 shows that the practice of EHs in Indonesia has been switched under the setting of Indonesian culture. It is obvious that this switching doesn't happen compulsorily. The major reason is most Indonesian people, particularly EFL learners, do not have cultural awareness. There are two likelihoods in terms of cultural awareness of this case. First, they considered the practice of EHs in native speaker version is not a big concern which means naturally they know how EHs are supposed to be. Second, they really do not know the practice of EHs in native speaker version. All indicate that cultural bearings are not loaded in language curriculum started from elementary school. English teachers teach English to EFL leaners without providing the information how EHs are supposed to practice in native speaker version. Or maybe the teachers themselves do not know and realize it.

\section{Discussion}

Vrbova (2006) argues that teaching foreign language without teaching at the same time its culture is futile. Brown and Yule (1991) state that if a learner is successful in understanding the target language, he / she needs to have good knowledge of cultural contents. The curriculum planners ought to provide learners with a sample of the cultural aspects so that they can share knowledge with native speakers. Related study discussing about Terms of Address in Korean and American Cultures provided by 
Herlina, R., \& Tarwana, W. (2020). EFL learners' perspective on English Honorifics (EHs) in Indonesia. Journal of Advanced Multidisciplinary Research, 1 (1), 32-45. DOI: http://dx.doi.org/10.30659/JAMR.1.1.32-45

Hwang (1991) has similarity and difference with the present study. The similarity of both studies lies on the culture awareness in learning language, in particular English language. The difference is on the target language. Hwang's target language is Korean language and the present study's target language is Indonesian language. Culture awareness in both studies are still the concern particularly in the practice of EHs in the target countries. People are many times aware of culture misunderstanding after they really experience it. So some of them pass through culture shock because they probably get stuck in native speaker's offence. EHs aim to respect people. However, the misunderstanding of EHs practice could degrade that respect.

In Indonesia, English is a foreign language taught in school started from elementary school to tertiary education level. In general, it is still considered one of difficult subjects. EFL learners deal much more with everything about language features, such as vocabulary, grammar, pronunciation, speaking, writing, reading, Translation and so on. In general, they never get the explanation about how culture of English is embedded in learning English language, for instance, addressing older people with real names in English culture is common without making them furious. In contrast, addressing older people in Indonesia must use IHs (mas addressing to a man (a stranger) and familiar man), mbak addressing to a female (stranger and familiar person), bung addressing to a male public figure and male stranger, pak addressing to father and other male with respect, $i b u$ addressing to mother and other women with respect). Thus, Indonesian people will get culture shock (Shieh, 2014) when a young English boy just calls the name to an older Indonesian person. In terms of the practice of EHs, which is one of the culture misunderstanding encounter in learning English, the teacher doesn't give its explanation to EFL learners under the reason that

Misunderstanding of EHs use in Indonesia has been lasting for decades. If this misuse of EHs is addressed to native speakers of English, they'll be offensive. The only reason is the absence of culture teaching during language learning which is very crucial. In this case the government must take into consideration the engagement of culture in language curriculum. The purpose is to avoid misunderstanding during the communication with native speakers of English worldwide. In short, the culture awareness of the EHs practice in Indonesia ought to be the major concern since it leads to severe impacts. Furthermore, teaching culture during learning language will increase students' motivation to learn that language much better. Sometimes they become autonomous language learners because of their high curiosity of the culture. As language educators, we teach our students learn about the culture of the language during teaching English whether or not we include it overtly in the curriculum (Kramsch, 2013).

\section{CONCLUSION}

The practice of EHs (Mr, Mrs, Miss, Sir, and Ma'am) in Indonesia is mostly adapted to IHs like $i b u$, bapak, nyonya. The only reason is the culture awareness, particularly the 
one that EPTs is practiced has not been constructed. Another reason is most Indonesian names do not have family names attached. Thus, Indonesian people take EHs as it is supposed to be in Indonesian setting which is not actually a significant problem, however it'll be a major concern if it is addressed to native speakers of English. Some of them could be probably offended if the EHs are misused due to the fact that EPTs have something to do with respectful address.

Based on earlier explanation, the teacher of foreign language has an important role in teaching its culture. He should avoid raising cultural issues that are offensive because his role is to help learners acquire the foreign culture. He may show the differences between the native culture and the foreign one without judging them. Learners should also understand that there is no culture that is superior to others. This will motivate them to study foreign cultures.

Teaching culture has an effective role in terms of teaching linguistic components and language skills. This also helps in changing the learner's attitudes towards foreign language speakers and their language. As a result, the learner may have a positive motivation in learning a foreign language. This research puts the main suggestion to teachers of English who teach EFL learners to always insert the culture bearings of target language, not to teach but provide the information about the culture of target language.

\section{REFERENCES}

Abbaspour, E., Nia, M. R., \& Zare, J. (2012). How to Integrate Culture in Second Language Education? Journal of Education and Practice. ISSN 2222-1735 (Paper) ISSN 2222-288X (Online) Vol 3, No 10, 2012.

Abushihab, I. (2016). The Effect of Cultural Awareness on Motivating Students to Learn English as a Foreign Language in Jordan. Journal of Foreign Languages, Cultures and Civilizations. June 2016, Vol. 4, No. 1, pp. 51-57 ISSN 2333-5882 (Print) 2333-5890 (Online)

Aghajanian, Derderian, A. \& Cong, W.C. (2012). How Culture Effects on English Language Learners' (ELL's) Outcomes, with Chinese and Middle Eastern Immigrant Students. International Journal of Business and Social Science. Vol. 3 No. 5; March 2012. 172. Washington State University United States of America

Allen, S. (2018). Here's How to Know the Difference between Miss, Mrs., and Ms.

Biggs, J. and Moore, P. (1993). The Process of Learning, Prentice-Hall, Australia cited in Kennedy, P., (2002). Learning Cultures and learning styles: mythunderstandings about adult (Hong Kong) Chinese learners. International Journal of Lifelong Education. Vol. 21, Nov. 5, 2002.

Brown, G and G. Yule (1991). Teaching the Spoken Language, New York: CUP. 
Herlina, R., \& Tarwana, W. (2020). EFL learners' perspective on English Honorifics (EHs) in Indonesia. Journal of Advanced Multidisciplinary Research, 1 (1), 32-45. DOI: http://dx.doi.org/10.30659/JAMR.1.1.32-45

Brown, P., and Levinson, S. (1978). "Universals in language usage: Politeness phenomena". In E. N. Goody (eds), Questions and Politeness: Strategies in Social Interaction. Cambridge: Cambridge University Press

Chastain, K. (1971). The development of modern language skills: Theory to practice. Chicago: Rand McNally.

Constantin, E.C, et.al. (2015). Developing cultural awareness. Procedia - Social and Behavioral Sciences 191 (2015). 696-699

Fraenkel, J.R. \& Wallen, N.E. (2007). Design and evaluate research in education. Sixth edition. McGraw-Hill. New York

Gardner, R. (1980). On the validity of affective variables in second language acquisition: Conceptual, contextual and statistical considerations. Language Learning, 30, (pp. 255-270).

Gardner, R. C., \& Lambert, W. E. (1972). Attitudes and motivation in second language learning. Rowley, Mass.: Newbury House.

Gay, G. (2002). Preparing for Culturally Responsive Teaching. Journal of Teacher Education. vol. 53, No. 2, $106-116$.

Genc, B and Bada, E. (2005). Culture in Language Learning and Teaching. https://www.researchgate.net/publication/292537872

Geng, Q. (2018). Cultural Frame and Translation of Pronominal Adverbs in Legal English. International Journal of Society, culture and Language. ISSN. 23292210 (online). 6(2).

Hermessi, T. (2016). Culture, globalization and L2 education. In R. Al-Mahrooqi \& D. Christopher (Eds.).Bridging the gap between education and Employment: English language education in foreign language contexts (pp. 279-319). Bern, Switzerland: Peter Lang.

Hijirida, Kyoto, and Ho-min Sohn 1983 "Commonality and Respect in Address and Reference Term Usages." Language Research, 19, 139-68.

Hwang, S. J. J. (1991). Terms of Address In Korean and American Cultures. Intercultural Communication Studies I: 2:1991. The University of Texas at Arlington Summer Institute of Linguistics

Keaton, S. A., \& Giles, H. (2016). Subjective health: The roles of communication, language, aging, stereotypes, and culture. International Journal of Society, Culture \& Language, 4(2). (pp. 1-10).

Kementrian Pendidikan Dan Kebudayaan Republik Indonesia. (2017). Buku mata pelajaran bahasa Inggris untuk SMP kelas 8 "When English Rings a Bell".

Kennedy, P. (2002), Learning culture and learning styles: myth-understanding about adult (Hong Kong) Chinese learners. International Journal of Lifelong Learning, Vol. 21, No. 5, September - October, 2003. 
Kitao, K. (2000). Teaching Culture in Foreign Language Instruction in the Unites States. Online documents at URL http://ilc2.doshisha.ac.jp/users/kkitao/library/article/culture.htm. [14.06.2004].

KOVÁCS, G. (2017). Culture in Language Teaching. A course design for teacher trainees. ACTA UNIV. SAPIENTIAE, PHILOLOGICA, 9, 3, (2017) 73-86. DOI: 10.1515/ausp-2017-0030

Kramsch, Claire. (2009). Third culture and language education. In: Cook, Vivien-Wei, Li. (eds), Contemporary applied linguistics. London: Continuum. (pp. 233-254).

Kramsch, C. (2013). Culture in foreign language teaching. Iranian Journal of Language Teaching Research 1(1): 57-78.

Liang, M.Y. (2016). Achieving Multimodal Cohesion during Intercultural Conversations. International Journal of Society, culture and Language. ISSN. 2329-2210 (online). 4(2).

Olatundun, I. O. (2009). What Is Cross-cultural Research? International Journal of Psychological Studies. Behavioural Studies Department, College of Management Sciences. Redeemer's University, Mowe, Ogun State, Nigeria. E-mail: toytundun@yahoo.com

Miles, M.B. \& Huberman, A.M \& Saldana, J. (2014). Qualitative data analysis. A method sourcebook. Third edition. Sage publication

Moeller, Aleidine Kramer-Nugent, Kristen. 2014. Building intercultural competence in the language classroom. In: Dhonau, Stephanie (ed.), Unlock the gateway to communication. Central States Conference Report. 1-18. Retrieved from: http://digitalcommons.unl.edu/cgi/viewcontent.cgi? article=1160\&context=teachle arnfacpub

Neff, P. and Rucynski, J. (2013) Tasks for Integrating Language and Culture Teaching. English Teaching Forum, No. 2, 18 - 23.

Nunan, D. \& Richards, J. C. (2015). Language learning beyond the classroom. ESL and Applied Linguistics Professional Series. Routledge. Taylor \& Francis Group. New York and London.

Pourkalhor, O. \& Esfandiari, N. (2017). Culture in Language Learning: Background, Issues and Implications. International Journal of English Language \& Translation Studies.5 (1), 23-32

Rajab, T. (2015). A Socio-Cultural Study of Pedagogical Practices inside Syrian EFL Classrooms. International Journal of Society, Culture and Language. ISSN 23292210 (online).

Sapir, E. (1949). Sound patterns in language. In D. G. Mandelbaum (Ed.), selected readings of Edward Sapir in language, culture and personality. Berkeley: University of California Press.

Shieh, C. J. (2014). Effects of culture shock and cross-cultural adaptation on learning satisfaction of mainland china students studying in taiwan. revista internacional de 
Herlina, R., \& Tarwana, W. (2020). EFL learners' perspective on English Honorifics (EHs) in Indonesia. Journal of Advanced Multidisciplinary Research, 1 (1), 32-45. DOI: http://dx.doi.org/10.30659/JAMR.1.1.32-45

Sociologia (riS). Special Issue on Organizational Innovation. Vol. 72, extra 2, 5767, noViembre 2014. ISSN: 0034-9712; eISSN: 1988-429X. DOI:10.3989/ris.2013.08.10

Stainer, F. (1971). Culture: A motivating factor in the French classroom. In C. Jay \& P. Castle (Eds.), French language education: The teaching of culture in the classroom. Springfield, IL: State Department of Public Instruction.

Sysoyev, P. V. \& Donelson L. R. (2002). Teaching Cultural Identity through Modern Language: Discourse as a Marker of an Individual's Cultural Identity. Online documents at URL http://www.actr.org/JER/issue4/11.htm

Turkan, S. and S. çelik (2007) Integrating Culture into EFL Texts and Classrooms: Suggested Lesson Plan, NovitasRoyal, vol. 1, 18 - 33.

Vrbova, L. (2006) Developing Cultural Awareness in ELT, Unpublished MA Thesis, University of Pardubice.

Wardhaugh, R. (1986). An Introduction to Sociolinguistics. Oxford: Basil Blackwell Ltd

Wardhaugh, M., Fuller, J.M. (2015). An Introduction to Sociolinguistics. Seven ${ }^{\text {th }}$ edition. Wiley Blackwell. 